\begin{tabular}{ll}
\hline \hline MINING AND METALLURGY INSTITUTE BOR & ISSN: 2334-8836 \\
& UDK: 622 \\
\hline \hline
\end{tabular}

UDK: 006.01:622(045)=20

DOI:10.5937/MMEB1303135S

Novica Staletović, Srdja Kovačević ${ }^{* *}$, Nedeljko Tucović ${ }^{* * *}$, Miša Kovačević ${ }^{* * * * *}$

\title{
METHODOLOGICAL FRAMEWORK FOR RISK ASSESSMENT IN THE FUNCTION OF MINING EQUIPMENT MAINTENANCE AND MANAGEMENT IMS (QMS, AMS, EMS and OHSAS) IN MINING COMPANIES
}

\begin{abstract}
This paper points out the opportunities and needs for integration the maintenance function with other management systems in accordance with the requirements of ISO 9001, ISO 14001, OHSAS 18001 as well as the new Standard ISO 55001. It defines the flowchart of risk assessment in the procedure of mining equipment maintenance as well as the methodological framework for risk assessment in the procedure of mining equipment maintenance. The proposed risk assessment model defines the criteria for probability of occurrence the hazardous events as the consequences that may arise, as well as the mechanisms for control the assessed risk. This risk assessment model can be also put in the context of integrated risk management.
\end{abstract}

Keywords: risk assessment, mining equipment, system of equipment management

\section{INTRODUCTION}

Mining companies and/or specific organizations involved in the maintenance of mining equipment are faced with various risks that may affect the realization of these objectives. Objectives may relate to a number of activities in the mining company, from strategic initiative for all operations, processes and projects and, can be reflected in terms of corporate social responsibility, meeting the requirements of legislation, commercial and financial measures.

Risk assessment involves the application of logical systematic methods for communication and consultation during the maintenance process of mining equipment. Risk assessment is that part of management which provides a structured process that analyzes the hazardous events that may cause the cancellation of mining equipment, and can lead to the incidents, accidents and accidents that are reflected in unplanned deadlock, breakdowns, environmental pollution, occupational injuries, fires and similar.

The objectives of development this methodological procedure of risk assessment for maintenance the mining equipment is to try to find the answers to the following questions:

- What might happen in the process of maintenance the mining equipment and why (identification of hazardous events that can cause failure or unplanned deadlock)?

\footnotetext{
*Faculty of Ecology and Environmental Protection Union University-Nikola Tesla, Belgrade ** EPS PC Open Pits Kosovo - Obilić, Zetska 15, Belgrade

**** AD Jugoinspekt Belgrade, Čika Ljubina 8, Belgrade

**** Certification Body YUQS Ltd.; Trg Nikole Pašića V, Belgrade
} 
- What is the probability of hazardous events that can cause a failure?

- Whether are there factors that can influence on reduction the probability of occurrence of hazardous events?

- Whether are the levels of estimated risk acceptable and whether they require further treatment?

This proposed methodological procedure of risk assessment comply with the general principles of risk assessment so that it can be used in other organizations-facilities for maintenance the machinery and other purposes, and design of integrated management systems in mining companies. The proposed procedure is compatible with the Standards IEC/FDIS 31010:2009 and AS/NZS ISO 31000:2009 [12], [13].

Organizations dealing with maintenance for a long time sought to improve their business, both from the point of view of interior organizatrion and optimization the maintenance systeme and the external costs of supply and pressure. Pressures In recent times, the pressures are more and more and they are reflected in the need for energy savings and increased employee safety and environmental protection. Thus, not surprisingly, is a development of a new standard ISO 55001 Asset Management Systems Requirements. [5]

Standards ISO 9000, 9001 and 9002 have been on the market since 1987, then the standard ISO 14001 since 1996 and BS OHSAS 18001 since 2000. It is a logical continuation of development the quality in the system of equipment maintenance and development the new standard ISO 55001, which is expected in early 2014.

Mining companies with established Integrated Management System (IMS), such as the quality management system (QMS) in accordance with ISO 9001, the equipment management system (AMS) in accordance with ISO 55001, the environmental management system (EMS) in accordance with ISO 14001, management system of occupational health and safety (OHSAS) in accordance with BS OHSAS 18001, can certainly expect that the effectiveness and efficiency of the company business will go upward, and that the company will contribute to the sustainable development both to the company and wider community as a whole.

\section{OBJECTIVE AND PURPOSE OF RISK ASSESSMENT IN MINING EQUIPMENT MAINTENANCE}

Risk assessment in the procedure maintenance of mining equipment is intended to provide the evidence based on identification and analysis of hazardous events that have occurred in the past or may occur and cause failure; how to treat the assessed risks and how to choose the best option of assessed risk management. Some of the main advantages of performing risk assessment include:

- Understanding the risk and its potential impact on the objectives of organization, which deals with the maintenance of mining equipment;

- Identification the critical points in the processes of mining equipment maintenance;

- Comparison of risk in the alternative technologies or approaches of mining equipment maintenance;

- Communication with assessed risk and uncertainties;

- Assistance in establishing the priority of actions to reduce the level of assessed risk;

- Contribution towards the prevention of incidents, accidents and accidents (emergencies);

- Selection of different forms of risk treatment in order to meet the requirements related to the management of mining equipment maintenance;

Providing the information that will help in assessment whether the risk is acceptable when compared to the pre-defined criteria. 


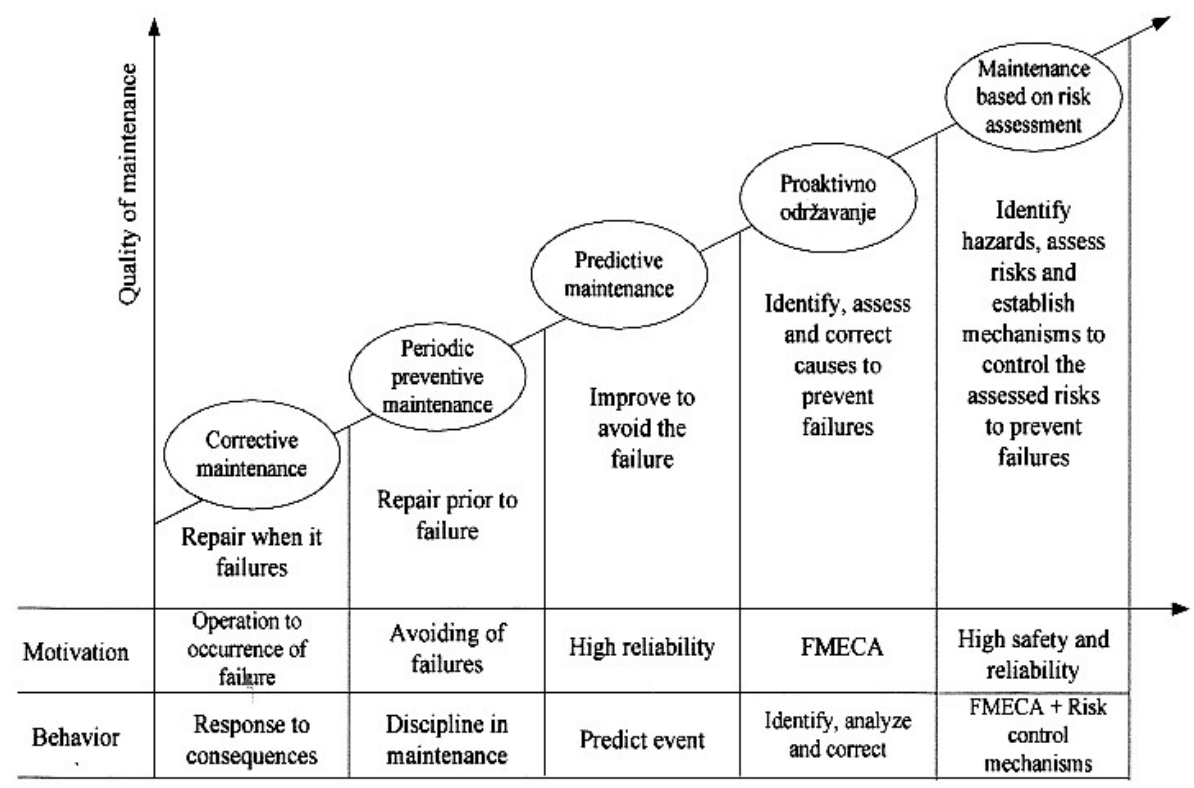

Figure 1 Development of conceptions for maintenance and increasing the quality [14]

\section{MANAGEMENT OF THE RISK QUALITY BASED ON RISK ASSESSMENT}

Equipment management strategy is systemic and coordinated activities by which the organization optimally and continuously improves its assets and equipment, its activities, risks and costs over the lifetime of equipment in order to achieve the defined strategic plan. [5]

The basic advantages from the standpoint of strategic management of equipment with optimal lifetime include:

- Satisfied clients (internal and external) due to the improved performance and control of products or services by certain standards;

- Improved health and safety at work;

- Improved environmental protection:
- Long-term planning and continuous performance;

- Improving the corporate reputation, whose benefits can be the increased share value, higher staff satisfaction and more effective and efficient procurement;

- The ability to demonstrate that demonstrate that sustainable development is actively represented in the mining equipment management.

Maintenance is the set of activities of administrative, organizational, technical and technological nature, aimed to the preservation and improvement the oeprating characteristics or insurance the state of main- 
tened means and in which it has the ability to perform the dedicated function [14].

Maintenance, based on risk management ,is the latest approach in risk assessment of failure the technical systems and consequences that such failure may cause on the operation of system. Introduction of the risk concept allows to model by more realistic the failure of technical systems and assessment the expected consequences. Specifically, the risk quantification allows determination the optimal level of risk.

The idea of maintenance, based on risk assessment, appeared in the late 80s of the last century in the United States. Sometime later, the first document (ASME 1991) was published. As the latest generation of maintenance based on reliability, a methodology was developed that is based on the risk assessment of failure component and the impact that this failure can cause on the operation of system (RBM Risk Based Maintenance). This approach is essentially no different from the RCM approach, except in the fact that the contribution to boosting the reliability level, in this case, is measured by degree of risk reduction.

The advantages of RBI are [15]:

- Determining the potential risks on technical system,

- Possibility of quantifying the benefits of maintenance procedures,

- By finding solutions in the field of maintenance,

- Optimal utilization the existing resources.

The fields of application the management on the basis of risk associated with maintenance activities are:
- Risks during the performance of maintenance activities,

- Risks as an integral part of the methodology of maintenance activities (organization of work, logistic support, motivation, education and training),

- Risk due to a lack of maintenance (staff reliability and human factors).

Since the failure of some component is essentially statistical process (probability of occurrence), the risk is an adequate size, which can serve as a reference for making decisions on maintenance activities. Risk management, therefore plays an important role in the maintenance of technical systems. If the probability of hazardous event occurrence is very low, then the risk of failure is small. It may be noted that the need for maintenance is quantified by the risk: the higher the risk the higher the need for maintenance.

The National standards for risk management appeared for the first time in Australia and New Zealand in 1995 [13], then in Canada in 1997, and in the UK in 2000. The risk assessment is a comprehensive process of identifying, analyzing and assessment of risk $^{5}$. Risk assessment provides to the decision makers and responsible parties an improved understanding the risks that may affect the achievement of objectives and adequacy and effectiveness of control that is already in force. This provides a basis for decisions about the most and appropriate approach used for the treatment of risk. The output of the risk assessment is input into decision making process in the organization. The following Figure 2 shows the general concept of risk assessment. 


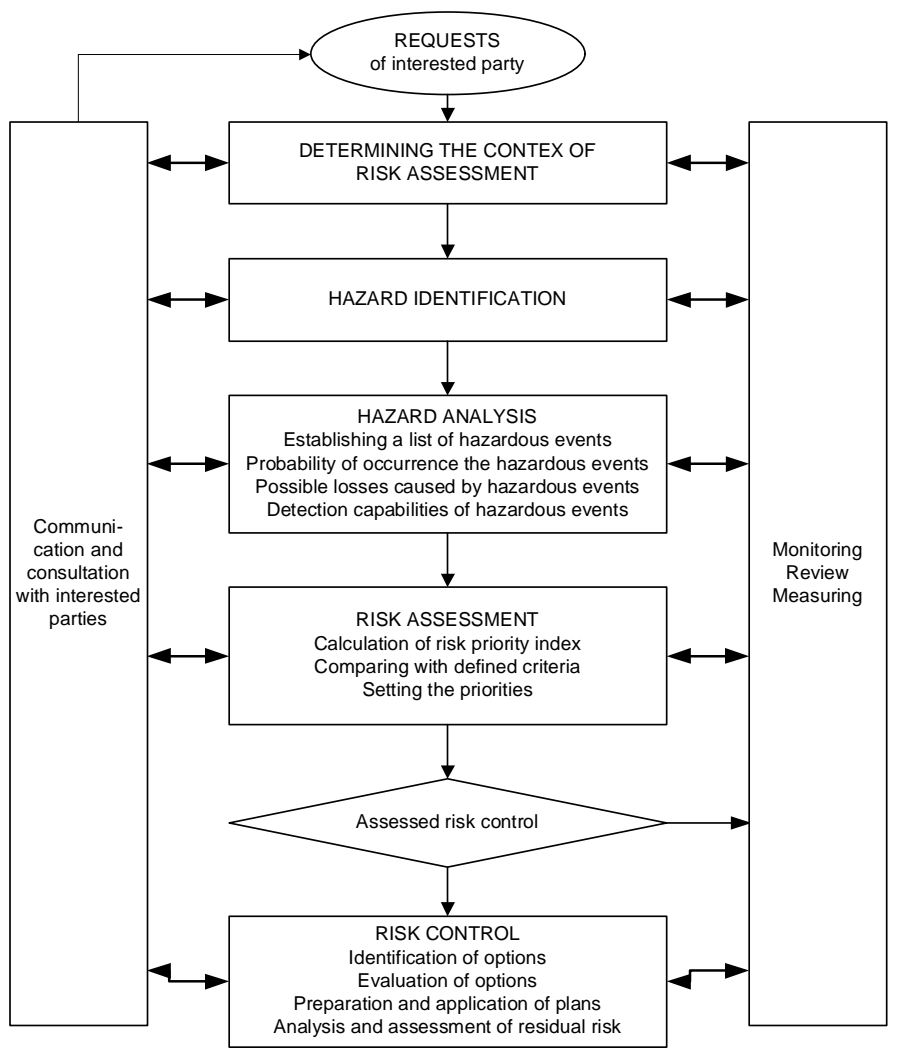

Figure 2 Process of risk assessment [8][12]

Understanding the term "quality" was constantly changed with the passage of time. The term "quality" was primarily related only to the product, then in the late of twentieth century spread to the processes and organization as a whole. The concept of sustainable development was developed along with it.

The term "quality" becomes meaningful only when it is placed in the context of characteristics of products and/or services that can be then specified in terms of standard or level of service. So, the quality is: overall feature and characteristic of products or services that lead to the customer/user satisfaction of service.

Risk management as a support to the achievement of quality objectives involves planning, control and reduction of risk wit- hin all aspects of quality. In recent years as a support to this, a large number of standards for risk management are developed such as: IEC/FDIS 31010:2009 and AS/NZS ISO 31000:2009.

The British Institute of Asset Management in cooperation with the British Standards Instution, published in 2004 PAS-55, the first publicly available specification for management of assets (equipment) organization. The specification has proved to be very successful, so the companies used it in the field of transport, mining and other forms of production. In 2008, the amendment of Specification (PAS 55: 2008) was made: The International Standards Organization (ISO) has adopted PAS 55: 2008 as the basis for development the new series ISO55000. The adoption of Standard is planned at the beginning of 2014. 
The new ISO 55001 Standard will define the requirements for certification in a way that is compatible with the series of Standard ISO 9000, ISO 14000, OHSAS 18000, etc.

In addition to compatibility with other management systems, the future standard will be applicable to the organizations of all sizes, from the Small and Medium Enterprises to the multinational organizations that want to establish a management system of equipment (fixed assets), in order to optimally and sustainably manage with their equipment during their life cycle.

Structure of ISO 55001 Standard will be largely similar to the other management systems as to require the existence of equipment management policy, strategies, objectives, plans, determining the representative members from the point of equipment management. Policy of equipment management should be based on the Strategic Plan in accordance with the nature of equipment and other organizational policies. It is necessary to define, in policy, the general framework of risk management in the organization or to comply with applicable legal, regulatory, statutory and other requirements and to clearly state the principles that will be applied as well as the organizational approach to the occupational health and safety, environmental protection and sustainable development.

In defining the plans of equipment management, it is necessary to take into account:

a) the risks associated with equipment which, if they are realized, may have the consequence of accident or emergency situation;

b) key potential delays in operation for equipment management;

c) activities to be taken to the aim of response to an accident and/or emergency and mitigating the consequences;

d) competence and training of staff on equipment maintenance to respond to emergencies;

e) the needs for risk holder that an accident and/or emergency situation can affect or that are required to respond to such situations.
The request of the future ISO 55001 Standard from the viewpoint of risk management is explicit that the organization should establish, implement and maintain the documented processes and/or procedures for identification and assessment the risks associated with equipment management, and to identify and implement the necessary control measures throughout the life cycle of equipment [17].

The methodology of the risk management should:

- be defined in relation to the field of application, nature and time in order to provide to be proactive rather than reactive, and

- ensure the identified, prioritized and documented risk, as well as control application, when it is appropriate.

Identification and assessment of risks in the process of equipment maintenance should take into consideration the possibility of real and potential hazardous events and their consequences, and should cover the risks associated with functional equipment failure, accidental or intentional equipment damage, then the operational risks including control of equipment, human factors and other factors, and activities that affect the performance, working conditions, occupational safety and environmental protection.

\section{PROPOSAL OF METHODOLOGI- CAL FRAMEWORK OF RISK AS- SESSMENT IN MINING EQUIP- MENT MAINTENANCE}

Methodological framework of risk assessment involves defining the criteria for risk assessment, as follows:

- Probability of occurrence the hazardous event that may cause failure of mining equipment;

- Nature and types of consequences that may relate to the process;

- Risk levels;

- Acceptable risk levels;

- Establishing the control mechanisms for assessed risks. 
Hazardous events can cause failures and usually are associated with particular factors. By the origin and course of action, the factors can be divided into: external and internal.

External factors are activities of various entities, events or occurrences, and physically are located outside the organization.

Internal factors are activities, events or occurrences, and physically are located within the organization.

Internal factors are usually:

- History of negative/hazardous events;

- Inconsistency of organization with the legislation;

- The size or dispersion of organization;
- Inadequate way of organizing the operation;

- Insufficient training of staff;

- Existing systems of equipment maintenance.

Possibility of realization the certain hazardous events that may cause a failure is shown by the risk level. The risk level is directly dependent on the frequency of occurrence the hazardous events, sensitivity of the system, and the current system state [10].

\subsection{Flowchart of risk assessment and management in the procedure of mining equipment maintenance}

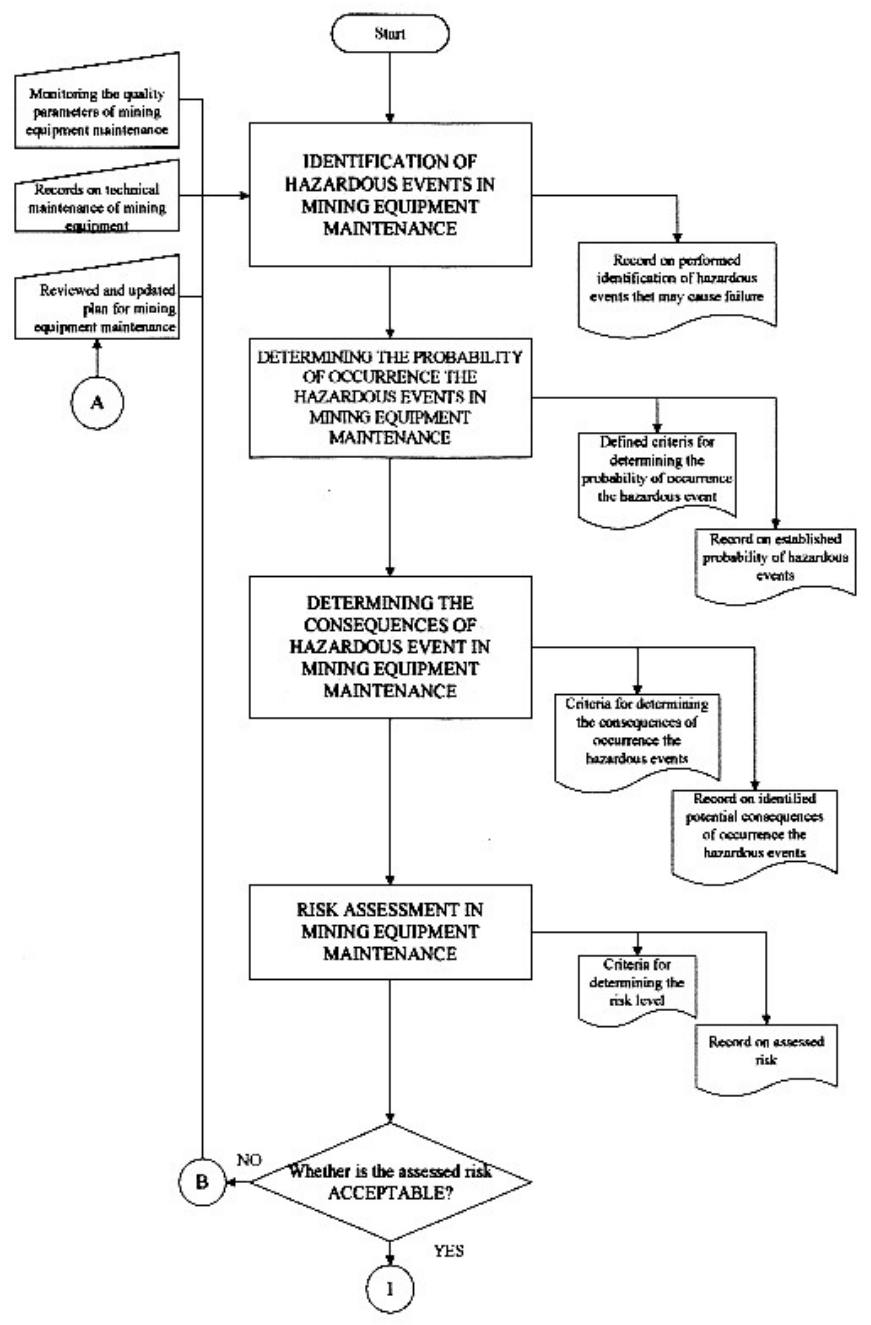




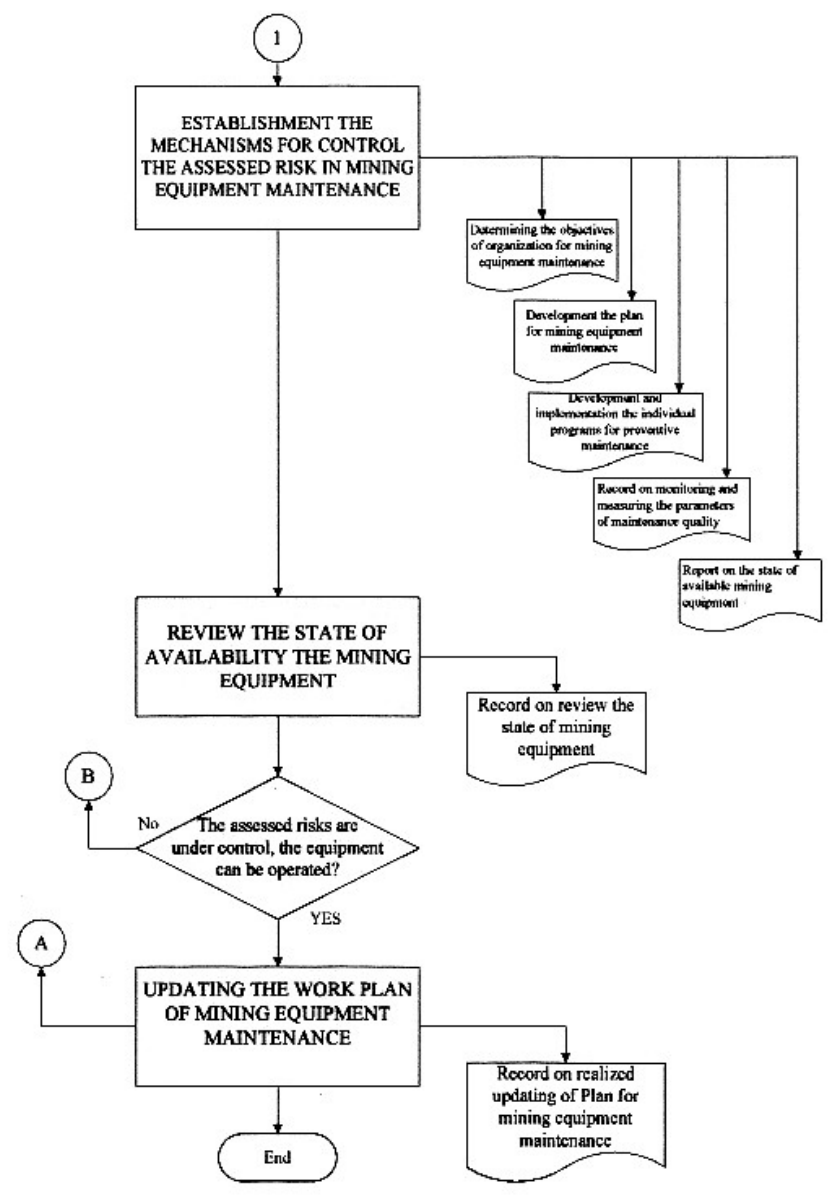

\subsection{Selection of Method and Criteria for Risk Assessment}

Risk assessment includes the probability of occurrence the hazardous events and consequences of realization the hazardous event that may cause a failure [12] and it can be expressed as follows.

$$
\mathbf{R}=\mathbf{V} \times \mathbf{P}
$$

Where:

$\mathbf{R}$ - risk level;

V - probability that potential hazard will result in potential hazardous event and cause failure;

P - consequences or effect that can put the hazardous event on the value of organization, natural and man-made values and environmental quality.

\subsubsection{Assessment the Probability of Hazardous Events}

Probability of occurrence the hazardous event that can cause the equipment failure $(\mathbf{V})$ is expressed according to the following expression:

$$
\mathbf{V}=\mathbf{U} \# \mathbf{R}
$$

$\mathbf{U}$ - frequency of occurrence the hazardous event that can cause the equipment failure; 
$\mathbf{R}$ - sensitivity to the possibility of realization the hazardous event.

Probability, that potential hazard results in hazardous event, is a combination of frequency the event of certain hazard and sensitivity of organization. Probability that a potential hazard results in hazardous event is graded as follows: 1 - very unlikely, 2 - unlikely, 3 - moderately likely, 4 probably, 5 - very likely.

Table 1 Criteria for determining the probability of hazardous event occurrence

\begin{tabular}{|c|c|c|c|}
\hline & Frequency - U & Sensitivity - R & V $=\mathbf{U} \# \mathbf{R}$ \\
\hline $\mathbf{1}$ & $\begin{array}{c}\text { very rare } \\
\text { occurrence of hazardous event }\end{array}$ & no maintenance function & $\begin{array}{c}\text { very } \\
\text { unlikely }\end{array}$ \\
\hline $\mathbf{2}$ & $\begin{array}{c}\text { high } \\
\text { occasional }\end{array}$ & unlikely \\
\hline $\mathbf{3}$ & $\begin{array}{c}\text { frequent } \\
\text { pojava opasnog događaja }\end{array}$ & only technical maintenance measures & $\begin{array}{c}\text { moderately } \\
\text { likely }\end{array}$ \\
\hline $\mathbf{4}$ & $\begin{array}{c}\text { low } \\
\text { prevailing } \\
\text { occurrence of hazardous event }\end{array}$ & $\begin{array}{c}\text { organizational and technical maintenance } \\
\text { measures }\end{array}$ & probably \\
\hline $\mathbf{5}$ & $\begin{array}{c}\text { very often } \\
\text { occurrence of hazardous event }\end{array}$ & in the function of system maintenance & very likely \\
\hline
\end{tabular}

Frequency refers to the repetition of certain threat that realization of hazardous even will be realized in the observed period of time Frequency is graded as follows: 1 - very rare, 2 - occasional, 3 - frequent, 4 - prevailing, and 5 - very often

Sensitivity presents the current state of maintenance system for equipment/fixed assets or sensitivity the organization/facility/process on hazard of failure. Sensitivity is graded as follows: 1 - very high vulne- rability - no measures of maintenance function, 2 - high vulnerability - only organizational maintenance measures in a function, 3 - mean vulnerability - only technical maintenance measures in a function, 4 - low vulnerability - organizational and technical maintenance measures in a function, 5 very low vulnerability - the established, certified and many time checked system of equipment management.

Table 2 Matrix for assessment the probability of failure

\begin{tabular}{|c|c|c|c|c|c|c|}
\hline \multicolumn{2}{|c|}{ SENSITIVITY } & very high & high & medium & low & very low \\
\cline { 2 - 7 } \multicolumn{2}{|c|}{ FREUENCY } & 1 & 2 & 3 & 4 & 5 \\
\hline very rare & 1 & 3 & 2 & 1 & 1 & 1 \\
\hline occasional & 2 & 4 & 3 & 2 & 2 & 1 \\
\hline frequent & 3 & 5 & 4 & 3 & 2 & 2 \\
\hline prevailing & 4 & 5 & 4 & 3 & 3 & 3 \\
\hline very often & 5 & 5 & 5 & 4 & 3 & 3 \\
\hline
\end{tabular}

\subsubsection{Consequences of Hazardous Event}

The consequences of hazardous even (P) are expressed according to the expression:

\section{$\mathbf{P}=\check{\mathbf{S}} \# \mathbf{K}$}

$\check{\mathbf{S}}$ - damage of specific mining machinery where hazardous event can cause consequences;

$\mathbf{K}$ - criticality, value or importance the protected value for organization in which the hazardous event can cause consequences.

Consequences present the effect of hazardous events on equipment (main assets) of organization, and they are manifested by the size of damage in relation to the critical importance of protected values.

Consequences are graded as follows: 1 - very light, 2 - light, 3 - medium severe, 4 - severe and 5 - very severe. 
Table 3 Criteria for determining the consequences

\begin{tabular}{|c|c|c|c|}
\hline & Damage - Š & Criticality - K & $\mathbf{P}=\stackrel{\mathbf{S}}{ } \# \mathbf{K}$ \\
\hline 1 & $\begin{array}{l}\text { very small - to } 1,000.00 \text { Euros or } \\
\text { very small consequences }\end{array}$ & $\begin{array}{l}\text { very large - complete } \\
\text { disruption in running the } \\
\text { organization }\end{array}$ & $\begin{array}{c}\text { very light } \\
\text { consequences }\end{array}$ \\
\hline 2 & $\begin{array}{l}\text { small - from } 1,000.00 \text { to } 10,000.00 \\
\text { Euros, or small consequences }\end{array}$ & $\begin{array}{l}\text { large-shaken functioning of } \\
\text { the organization }\end{array}$ & $\begin{array}{l}\text { light conse- } \\
\text { quences }\end{array}$ \\
\hline 3 & $\begin{array}{c}\text { medium - from } 10,000.00 \text { to } \\
100,000.00 \text { Euros or serious } \\
\text { consequences }\end{array}$ & $\begin{array}{c}\text { medium - possible } \\
\text { functioning with increased } \\
\text { efforts and additional re- } \\
\text { sources } \\
\end{array}$ & $\begin{array}{l}\text { medium se- } \\
\text { vere conse- } \\
\text { quences }\end{array}$ \\
\hline 4 & $\begin{array}{c}\text { large - more than } 100,000.00 \text { Euros, or } \\
\text { severe and multiple serious } \\
\text { consequences }\end{array}$ & $\begin{array}{l}\text { small - possible stopping of } \\
\text { the working process }\end{array}$ & $\begin{array}{l}\text { severe conse- } \\
\text { quences }\end{array}$ \\
\hline 5 & $\begin{array}{l}\text { very large - more than a million Euros } \\
\text { or catastrophic consequences }\end{array}$ & $\begin{array}{l}\text { very small - solving on the go } \\
\text { by regular activities }\end{array}$ & $\begin{array}{l}\text { very severe } \\
\text { consequences }\end{array}$ \\
\hline
\end{tabular}

Damage is a measure of damage the protected value (equipment/fixed assets) and it can result in various degrees. Damage is graded and expressed as: 1-very small damage, 2-small damage, 3-medium damage, 4-large damage and 5-very large damage.
Criticality is a measure of value or importance of protected value.

Criticality is graded as follows: 1 - very large, 2 - large, 3 - medium, 4 - small and 5 - very small.

Table 4 Matrix for assessment the consequences

\begin{tabular}{|l|c|c|c|c|c|c|}
\hline \multicolumn{2}{|c|}{ CRITICALITY } & very large & large & medium & small & very small \\
\cline { 3 - 7 } DAMAGE & 1 & 2 & 3 & 4 & 5 \\
\hline very small & 1 & 3 & 2 & 1 & 1 & 1 \\
\hline small & 2 & 4 & 3 & 2 & 2 & 1 \\
\hline medium & 3 & 5 & 4 & 3 & 2 & 2 \\
\hline large & 4 & 5 & 4 & 3 & 3 & 3 \\
\hline very large & 5 & 5 & 5 & 4 & 3 & 3 \\
\hline
\end{tabular}

\subsubsection{Defining the Risk Level}

The risk level is graded as:

1) Very small (or negligible) risk $(\mathrm{R}=1$ and 2$)$

2) Low risk ( $\mathrm{R}=3,4$ and 5)
3) Moderately increased risk $(R=6,8$ and 9)

4) High risk ( $R=10,12,15$ and 16)

5) Very high risk $(R=20$ and 25$)$

Table 5 Matrix for risk assessment

\begin{tabular}{|l|c|c|c|c|c|c|}
\hline \multirow{2}{*}{$\begin{array}{l}\text { CONSEQUENCES OF } \\
\text { PROBABILITIES }\end{array}$} & very light & light & $\begin{array}{c}\text { medium } \\
\text { severe }\end{array}$ & severe & $\begin{array}{c}\text { extremely } \\
\text { severe }\end{array}$ \\
\cline { 3 - 7 } & 1 & 2 & 3 & 4 & 5 \\
\hline very unlikely & 1 & 1 & 2 & 3 & 4 & 5 \\
\hline unlikely & 2 & 2 & 4 & 6 & 8 & 10 \\
\hline moderate likely & 3 & 3 & 6 & 9 & 12 & 15 \\
\hline likely & 4 & 4 & 8 & 12 & 16 & 20 \\
\hline very likely & 5 & 5 & 10 & 15 & 20 & 25 \\
\hline
\end{tabular}


The assessed risks are classified, according to the defined categorization, into:

1) Acceptable Risk ( $R=1,2,3,4$ and 5)

2) Conditionally Acceptable Risk $(\mathrm{R}=6,8,9)$

3) Unacceptable Risk ( $\mathrm{R}=10,12,15$, 16, 20 and 25)

Upon completion the risk assessment process, the approach is aimed to the establishment the control mechanisms of assessed risk. Selection the appropriate option for establishment the mechanisms of risk control involves balancing the costs and efforts in application the option and benefits that can be drawn from it [8].

Large number of options for establishment the mechanisms of risk control can be considered and applied individually or in combination. In deciding, take into account rare, but the risks that can justify the actions of establishment risk control mechanisms that are not justified (permitted) by the strict economic rules [10].

In defining the risk management or considering the changes in the current management, the measures and options of risk reduction must be considered according to the following hierarchy:

a) measures and options for elimination or avoiding the risks;

b) measures and options for mitigation or replacement (substitution) the risks;

c) measures and options for engineering control the feasibility of applied strategies, plans and programs and the analysis of price and benefits;

d) measures and options for defining the procedures and guidelines for equipment maintenance;

e) measures and options for implementation the technical diagnostics.

\section{CONCLUSIONS}

Mining companies that want to grow their business must have at all times the relevant information on what equipment/fixed assets are available and in a functional condition. Analysis the condition of equipment/fixed assets needs to devote the sufficient attention because, in this way, the company management has important information that encourage the adoption of appropriate decisions for improvement the system of equipment management as well as overall integrated management system. A very important step in development of equipment maintenance system is the inclusion of top management and personnel responsible for operation and maintenance of equipment.

Defined flowchart and methodological procedure of risk assessment in the process of maintenance the equipment/fixed assets is of great benefit to development the system of equipment management (AMS). Risk assessment and establishment the control mechanisms management is of great benefit in the design of integrated management systems [8]. The proposed model of risk assessment allows properly processing and usage the information on risk in maintenance in decision-making at the relevant levels of organization [8].

Methodology of risk management is proposed and defined in maintenance of mining equipment, that:

- provides to be proactive, not reactive, and

- provides the identification, prioritized and documented risks, as well as implementation of control, when it is appropriate.

Proactive and comprehensive risk assessment, as it is defined in this paper, is an organization that deals with mining equipment maintenance of mining equipment and it can:

- create and approve the policy of assessed risk management;

- inform all interested parties (employers, management, customers, etc/) for the state of availability of its mining equipment;

- define the control mechanisms of assessed risk that matches the performances of organization for mining equipment maintenance;

- ensures compatibility of risk management objectives in mining equipment 
maintenance with the objectives and strategy of organization;

- provides compliance with the law and bylaw legislation as well as legal documents of organization pertaining quality management of mining equipment maintenance;

- provides a distribution of needed resources for assessed risk management.

\section{REFERENCES}

[1] Asset Management Consulting Limited brochure: Asset Management Excellence (2010)

[2] Australian Emergency Management Committee, 2009: National Emergency Risk Assessment Guidelines, Tasmanian State Emergency Service, Hobart.

[3] Anđelković B., Staletović N., Preventive Engineering in the Field of Fire in Design of Technological Systems, Preventive Engineering, No. 2. Dunav Preving, Belgrade, 1999, pp. 27-31.

[4] BSI: Asset Management-Overview, Principles and Terminology, ISO PC 251/N48

[5] Curović D., Gavrilović M.; Asset Management - Series of Standard ISO 55000; Quality and Excellence, No. 910; Belgrade 2012.

[6] European Standard EN 15341 - Maintenance - Key Performance Indicators.

[7] Kovačević S.; Staletović N.; Tucović N.; Methodological Approach to Risk Assessment in a Function of System Management of Occupational Health and Safety in PU OP "Kosovo" Business Policy - Quality, ISSN 03542408 - UDC 006 +658.5; First XXI Nos. 10-11, 2011.

[8] Kovačević S., Staletović N., N. Tucović, R. Janković; Quantitative Assessment of Risk Management in the Function of Integrated Systems, 14.DQM, International Conference of
Quality Management and Reliability ICDQM - 2011, (ISBN 978-8686355-05-8, pp.159-165), 29-30 June 2011, Belgrade, Serbia.

[9] Petrović D., Damnjanović Z., Đenadić D., Pantović R., Milić V., Application of Modern Computer Devices and Tools to Reduce Accidents in the Mining Systems, Mining Engineering, Bor, No. 2, pp. 29-40, 2010.

[10] Staletović N, Kovačević S., Kovačević M.; Methodological Approach to Identification of Aspects and Evaluation the Impacts on the Environment for the Project "Exploitation of Magnesite in the Deposit Čavlovac Masnica"; Mining Engineering, 2012; ISSN 1451-0162.

[11] Staletović N.; Evaluation of OH\&S Risks in a Function of Preventive Engineering and Integrated Management Systems (QMS/EMS/OHSAS); Technique - Menadžment, Vol. 59, No. 3, pp. 8-14, 2009.

[12] Standard IEC/FDIS 31010:2009(E) Risk Management - Risk Assessment Techniques

[13] Standards Australia and Standards New Zealand; Standard Risk Management AS/NZS 4360:2009. Sydney and Wellington: Standards Australia and Standards New Zealand.

[14] Papić Lj.; Preventive Management, Research Centre DQM, Čačak, 1998, pp.109.

[14] Papić Lj., Milovanović Z; Maintenance and Reliability of Technical Systems, DQM, Prijevor, 2007.

[16] www.umsgroup.com

[17] www.pragma world.net

[18]http://en.wikipedia.org/wiki/Asset_mana gement

[19] http://theiam.org/what-asset-management 


\begin{tabular}{ll}
\hline \hline INSTITUT ZA RUDARSTVO I METALURGIJU BOR & ISSN: 2334-8836 \\
& UDK: 622 \\
\hline \hline
\end{tabular}

\author{
Novica Staletović, Srdja Kovačević, Nedeljko Tucović ${ }^{* * * *}$ Miša Kovačević ${ }^{* * * *}$ \\ METODOLOŠKI OKVIR PROCENE RIZIKA U FUNKCIJI \\ ODRŽAVANJA RUDARSKE OPREME I UPRAVLJANJA IMS \\ (QMS, AMS, EMS i OHSAS) U RUDARSKIM KOMPANIJAMA
}

Izvod

U ovom radu ukazane su mogućnosti $i$ potrebe integracije funkcije održavanja sa ostalim menadžment sistemima u skladu sa zahtevima ISO 9001, ISO 14001, OHSAS 18001 kao i novog standarda ISO 55001. Definiše se dijagram toka procene rizika u postupku održavanja rudarske opreme kao i metodološki okvir za procenu rizika u postupku održavanja rudarske opreme. Predloženi model procene rizika definiše kriterijume za verovatnoću pojave opasnih događaja kao posledice koje se mogu javiti kao i mehanizme za kontrolu procenjenog rizika. Ovaj model procene rizika se može staviti $i$ u kontekst integrisanog upravljanja rizicima.

Ključne reči: procena rizika, rudarska oprema, sistem menadžmenta opremom

\title{
1. UVOD
}

Rudarske kompanije i/ili specifične organizacije koje se bave održavanjem rudarske opreme suočavaju se sa različitim rizicima koji mogu uticati na ostvarivanje zadatih ciljeva. Ciljevi se mogu odnositi na niz aktivnosti u rudarskoj kompaniji, od strateške inicijative za sve operacije, procese i projekte i mogu se ogledati u pogledu društveno odgovornog poslovanja, ispunjenja uslova zakonske regulative, komercijalnih i finansijskih mera.

Procena rizika obuhvata primenu logičkih sistematskih metoda za komunikaciju i konsultaciju tokom procesa održavanja rudarske opreme. Procena rizika je onaj deo upravljanja koji obezbedjuje struktuirani proces, koji analizira opasne događaje koji mogu uzrokovati otkaz rudarske opreme, a može uzrokovati incidente, akcidente i udese

koji se ogledaju u neplaniranom zastoju, havariji, zagađenju životne sredine, povredi na radu, požaru i tsl.

Ciljevi razvoja ovog metodološkog postupka procene rizika pri održavanju rudarske opreme je da se pokušaju naći odgovori na sledeća pitanja:

- Šta se može desiti u postupku održavanja rudarske opreme i zašto (identifikacija opasnih događaja koji mogu uzrokovati otkaz ili neplanirani zastoj)?

- Koja je verovatnoća pojave opasnih događaja koji mogu uzrokovati otkaz?

- Da li postoje faktori koji mogu da utiču na smanjenje verovatnoće pojave opasnih događaja?

- Da li su nivoi procenjenog rizika prihvatljivi i da li zahteva dalji tretman?

\footnotetext{
*Fakultet za ekologiju i zaštitu životne sredine Univerzitet UNION-NIKOLA TESLA Beograd ${ }^{* * *}$ EPS JP Površinski kopovi Kosovo - Obilić, ul. Zetska br. 15 Beograd ${ }^{*}$ AD Jugoinspekt Beograd, Čika Ljubina 8, Beograd

${ }^{* * * * *}$ Sertifikaciono telo YUQS d.o.o; Trg Nikole Pašića V Beograd
} 
Ovaj predloženi metodološki postupak procene rizika pridržava se opštih principa procene rizika tako da se može koristiti i u drugim organizacijama/postrojenjima za održavanje mašina i za druge svrhe i projektovanjaintegrisanih menadžmen sistema u rudarskim kompanijama. Predloženi postupak je kompatibilan sa standardima IEC/FDIS 31010:2009 i AS/NZS ISO 31000:2009 [12], [13].

Organizacije koje se bave održavanjem u dugom vremenskom periodu su nastojale da unaprede svoje poslovanje, kako iz ugla unutrašnjeg uređenja i optimizacije sistema održavanja tako i od spoljašnjih troškova isporuke i pritisaka. Pritisci su u novije vreme sve veći i ogledaju se u potrebi uštede energije i većoj bezbednosti zaposlenih i zaštite životne sredine. Shodno tome i nije iznenađenjeda se razvija novi standard ISO 55001 Asset Management Systems Requirements. [5]

Standardi ISO 9000, 9001 i 9002 su na tržištu od 1987, zatim standard ISO 14001 od 1996 i standard BS OHSAS 18001 od 2000. To je logičan nastavak razvoja kvaliteta u sisremu održavanja opreme i razvoja novog standarda ISO55001, koji se očekuje početkom 2014 godine.

Rudarske kompanije sa uspostavljenim integrisanim menadžment sistemima (IMS) kao što su sistem menadžmenta kvalitetom (QMS) u skladu skladu sa ISO 9001, sistem menadžmenta opremom (AMS) u skladu sa ISO 55001, sistem menadžmenta zaštitom životne sredine (EMS) u skladu sa ISO 14001 i sistem menadžmenta zaštitom zdravlja i bezbednosti na radu (OHSAS) u skladu sa BS OHSAS 18001 sasvim sigurno mogu očekivati da će efektivnost i efikasnost poslovanja kompanije ići uzlaznom linijom, da će kompanija dati svoj doprinos održivom razvoju kako kopanije tako i šire društvene zajednice u celini.

\section{CILJ I SVRHA PROCENE RIZIKA PRI ODRŽAVANJU RUDARSKE OPREME}

Procena rizika u postupku održavanja rudarske opreme ima svrhu da obezbedi dokaz na bazi identifikacija i analiza opasnih događaja koji su se u ranijem periodu dogodili ili se mogu dogoditi i uzrokovati otkaz, kako tretirati procenjene rizike i kako odabrati najpovoljniju opciju upravljanja procenjenim rizikom. Neke od glavnih prednosti vršenja procena rizika uključuju:

- Razumevanje rizika i njegov potencijalni uticaj na ciljeve organizacije koja se bavi održavanjem rudarske opreme;

- Identifikacija kritičnih tačaka u procesima održavanja rudarske opreme;

- Poređenje rizika u alternativnim tehnologijama ili pristupima održavanja rudarske opreme;

- Komunikacija sa procenjenim rizikom i neizvesnosti;

- Pomoć kod uspostavljanja prioriteta postupanja u cilju smanjenja nivoa procenjenog rizika;

- Doprinos sprečavanju incidenata, akcidenata i udesa (vanrednih situacija);

- Izbor različitih oblika tretmana rizika u cilju ispunjenja zahteva $u$ vezi sa upravljanjem održavanjem rudarske opreme;

- Pružanje informacija koje će pomoći u proceni da li je rizik prihvatljiv kada se uporedi sa unapred definisanim kriterijumima. 


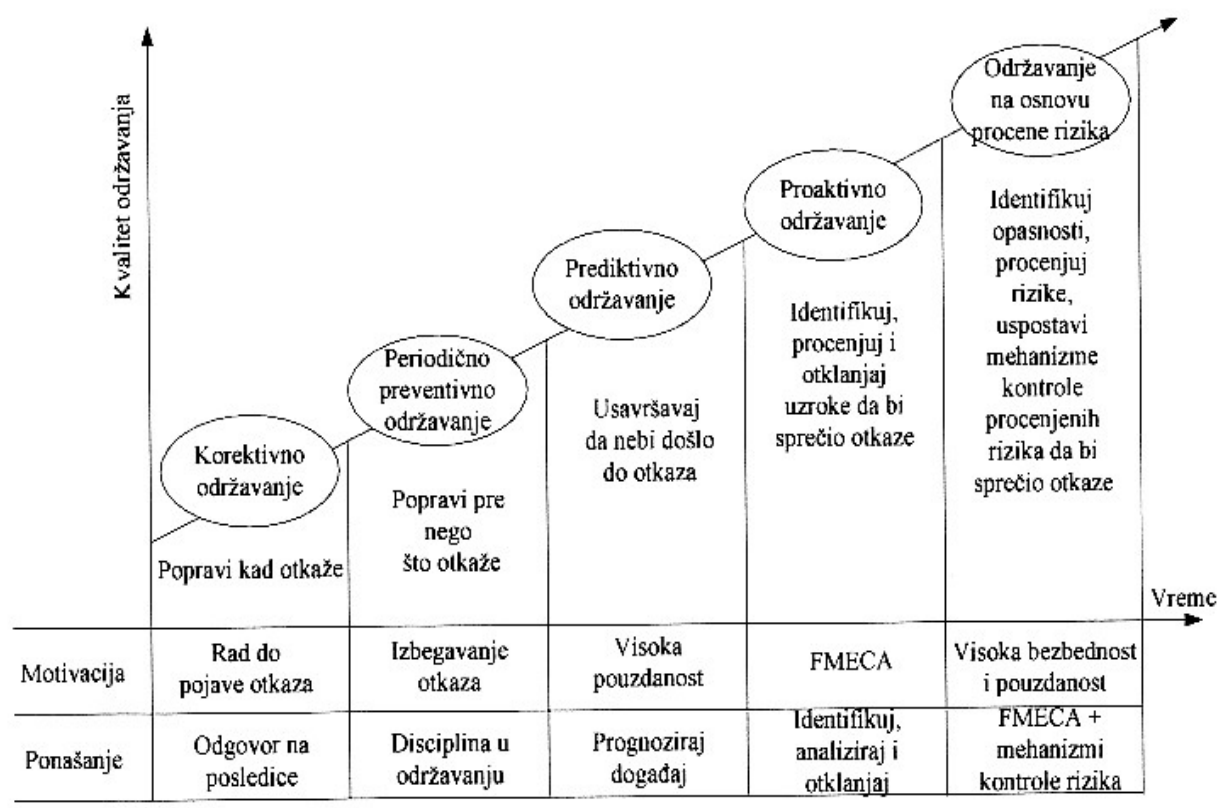

SI. 1. Razvoj koncepcija održavanja i povećanje kvaliteta [14]

\section{UPRAVLJANJE KVALITETOM \\ ODRŽAVANJA NA BAZI \\ PROCENE RIZIKA}

Strategija upravljanja opremom predstavlja sistemske i koordinirane aktivnosti pomoću kojih organizacija optimalno i kontinualno unapređuje svoja sredstva i opremu, svoje aktivnosti, rizike i troškove tokom veka trajanja opreme u cilju postizanja definisanog strateškog plana. [5]

Osnovne prednosti sa stanovišta strateškog upravljanja opremom sa optimalnim vekom trajanja podrazumeva:

- zadovoljne klijente (unutrašnji i eksterni) zbog poboljšanog učinka i kontrole proizvoda ili usluge po određenim standardima;

- poboljšana zaštita zdravlja i bezbednost na radu;

- poboljšana zaštita životne sredine;
- dugoročno planiranje i kontinuirani učinak;

- poboljšanje korporativne reputacije, čije prednosti mogu biti povećana vrednost akcija, veća satisfakcija osoblja i efektivnija i efikasnija nabavka;

- sposobnost da se demonstrira da je održivi razvoj aktivno zastupljen $\mathrm{u}$ upravljanju rudarskom opremom.

Održavanje predstavlja skup aktivnosti administrativnog, organizacijskog, tehničkog i tehnološkog karaktera, čiji je cilj očuvanje i poboljšanje radnih karakteristika ili osiguranje stanja održavanog sredstva, a u kojem ono ima sposobnost obavljanja namenske funkcije [14] 
Održavanje zasnovano na risk managementu je najnoviji pristup u oceni rizika otkaza tehničkih sistema i posledica koje takav otkaz može da prouzrokuje na funkcionisanje sistema. Uvođenje pojma rizika omogućuje da se na realističniji način modeluje otkaz tehničkih sistema i procene očekivane posledice. Tačnije, kvantifikacija rizika omogućuje određivanje optimalnog nivoa rizika.

Ideja o održavanju na bazi procene rizika pojavila se kasnih 80-tih godina prošlog veka u SAD. Nešto kasnije, publikovan je i prvi dokument (ASME 1991). Kao najnovija generacija održavanja zasnovanog na pouzdanosti razvila se i metodologija koja se bazira na proceni rizika otkaza komponente i uticaja koji taj otkaz može da prouzrokuje na funkcionisanje sistema (RBM - Risk Based Maintenance). Ovaj pristup u suštini se ne razlikuje od RCM pristupa, osim u cinjenici da se doprinos povišenju nivoa pouzdanosti $\mathrm{u}$ ovom slučaju vrednuje kroz stepen smanjenja rizika.

Prednosti RBI su [15]:

- određivanje potencijalnih rizika na tehničkom sistemu,

- mogućnost kvantifikovanja koristi postupaka održavanja,

- pomoću pronalaženju rešenja u oblasti održavanja,

- optimalno iskorišćenje postojećih resursa.

Oblasti primene upravljanja na bazi rizika u vezi sa aktivnostima održavanja su:

- rizici tokom izvođenja aktivnosti održavanja,
- rizici kao integralni deo metodologije aktivnosti održavanja (organizacija rada, logistička podrška, motivacija, edukacija i trening),

- rizik zbog nedovoljnog održavanja (pouzdanost osoblja i ljudski faktor).

Pošto je otkaz neke komponente $\mathrm{u}$ suštini statistički proces (verovatnoća pojave), rizik je adekvatna veličina koja može da posluži kao orjentir za donošenje odluka o aktivnostima održavanja. Upravljanje rizikom, samim tim ima bitnu ulogu u održavanju tehničkih sistema. Ukoliko je verovatnoća pojave opasnog događaja veoma mala, onda je rizik otkaza mali. Može se primetiti da je potreba za održavanjem kvantifikovana rizikom: što je veći rizik to je veća potreba za održavanjem.

Nacionalni standardi za menadžment rizikom prvi puta su se pojavili u Australiji i Novom Zelandu 1995. godine [13], zatim u Kanadi 1997. godine i u Velikoj Britaniji 2000. godine. Procena rizika je sveobuhvatan proces identifikovanja, analize i procene rizika (ISO TC 223/SC: Upravljanje rizicima - Uputstvo o principima i implementaciji upravljanja rizicima). Procena rizika obezbeđuje donosiocima odluka i odgovornim stranama poboljšano razumevanje rizika koji mogu uticati na ostvarenje ciljeva i adekvatnost i efektivnost kontrole koja je već na snazi. Ovo obezbeđuje osnovu za odluke o većini i odgovarajući pristup koji se koristi za tretman rizika. Izlaz procene rizika je ulaz u procesim odlučivanja $u$ organizaciji. Na sledećoj slici 2., prikazan je opšti koncept procene rizika. 


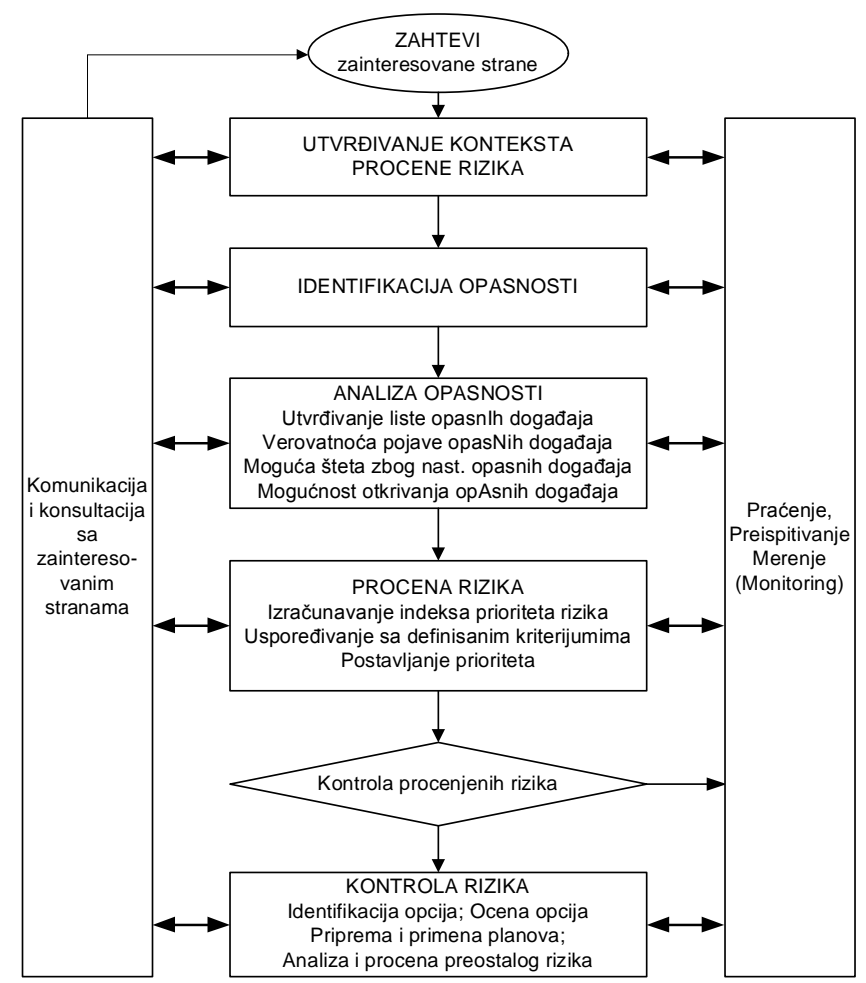

SI. 2. Proces procene rizika [8] [12]

Razumevanje pojma "kvalitet" se sa protekom vremena stalno menjao. Pojam "kvalitet" se najpre odnosio samo na proizvod, da bi se krajem XX veka proširio na procese i organizaciju u celini. Paralelno sa ovim razvijao se i concept održivog razvoja.

Termin "kvalitet" dobija značenje tek kada se stavi u kontekst karakteristika proizvoda i/ili usluga koje se zatim mogu specificirati u smislu standard ili nivoa usluge. Prema tome kvalitet je: sveukupna odlika i karakteristika proizvoda ili usluga koje vode ka - zadovoljenju kupca/korisnika usluge.

Upravljanje rizikom kao podrška ostvarenju ciljeva kvaliteta podrazumeva planiranje, kontrolu i redukciju rizika u okviru svih aspekata kvaliteta. U novije vreme kao podrška tome razvijen je veći broj standard za upravljanje rizikom kao što su: IEC/FDIS 31010:2009 i AS/NZS ISO 31000:2009.
British Institute of Asset management $\mathrm{u}$ saradnji sa British Standards Instution, objavio je 2004 godine PAS 55 - prvu javno dostupnu specifikaciju za upravljanje osnovnim sredstvima (opremom) organizacije. Specifikacija se pokazala kao veoma uspešna, tako da su je koristila preduzeća iz oblasti saobraćaja, rudarstva i drugih vidova proizvodnje. U toku 2008 godine izvršena je izmena specifikacije (PAS 55: 2008). The International Standards Organization (ISO) je prihvatila PAS 55: 2008 kao osnovu za razvoj nove serije ISO 55000. Usvajanje standarda se planira za početak 2014. godine.

Novi standard ISO 55001 definisaće zahteve za sertifikaciju i to na način da bude kompatibilan sa serijama standard ISO 9000, ISO 14000, OHSAS $18000 \mathrm{i}$ tsl.

Pored kompatibilnosti sa drugim menadžment sistemima budući standard ce biti 
primenljiv organizacije svih veličina, od malih i srednjih preduzeća do multinacionalnih organizacija koje žele da uspostave sistem menadžmenta opremom (osnovnim sredstvima), kako bi optimalno i održivo upravljala svojom opremom tokom njihovog životnog ciklusa.

Struktura standard ISO 55001 će u mnogome biti slična drugim menadžment sistemima tako da se zahteva postojanje politike upravljanja opremom, strategije, ciljeva, planova, određivanje predstvanika rukovodstva sa stanovišta upravljanja opremom. Politika menadžmenta opremom treba da bude zasnovana na strateškom planu u skladu sa prirodom opreme i sa drugim organizacionim politikama. U politici je potrebno definisati i opšti okvir menadžmenta rizika u organizaciji odnosno da bude u skladu sa važećim zakonskim, regulatornim, statusnim i drugim zahtevima i da jasno navede principe koji će se primenjivati kao što su organizacioni pristup zaštiti zdravlja i bezbednosti na radu, zaštiti životne sredine i održivom razvoju.

Pri definisanju planova menadžmenta opremom neophodno je uzeti u obzir:

a) rizike vezane za opremu koji ukoliko se ostvare mogu imati posledicu nezgoda ili vanrednu situaciju;

b) potencijalne zastoje $u$ radu ključne za menadžment opremom;

c) aktivnosti koje će se preduzeti u cilju odgovora na nezgodu i/ili vanrednu situaciju i ublažavanje posledica;

d) kompetenciju i obučenost zaposlenih na održavanju opreme da odreaguju na vanredne situacije;

e) potrebe nosioca rizika na koje nezgoda i/ili vanredna situacija može uticati ili koji su obavezni da odreaguju na takve situacije.

Sam zahtev budućeg standarda ISO 55001 sa stanovišta menadžmenta rizikom je eksplicitan da organizacija treba da ustanovi, primeni i održava dokumentovane procese i/ili procedure za identifikaciju i procenu rizika vezanih za menadžment opremom, i za identifikaciju i primenu potrebne mere kontrole tokom životnog ciklusa opreme [17].

Sama metodologija organizacije za menadžment rizika treba da:

- bude definisana u odnosu na područje primene, prirodu i vreme kako bi obezbedila da bude proaktivna, a ne reaktivna, i

- obezbedi identifikaciju, određivanje prioriteta i dokumentovanost rizika, kao i primenu kontrole, kada je to prikladno.

Identifikacija i procena rizika u procesu održavanja opremom treba da uzme $u$ razmatranje mogućnost stvarnih i potencijalnih opasnih događaja i njihovih posledica i treba da pokriva rizike vezane za funkcionalni kvar opreme, nenamerno ili namerno oštećenje opreme, zatim operativne rizike uključujući i kongrolu opreme, ljudske faktore i druge faktore i aktivnosti koje utiču na učinak, uslove rada, bezbednost na radu i zaštitu životne sredine.

\section{PREDLOG METODOLOŠKOG OKVIRA PROCENE RIZIKA U ODRŽAVANJU RUDARSKE OPREME}

Metodološki okvir procene rizika obuhvata definisanje kriterijuma za procenu rizika i to:

- verovatnoću pojave opasnog događaja koja može uzrokovati otkaz rudarske opreme;

- prirodu i tipove posledica koje se mogu odnositi na proces;

- nivoe rizika;

- prihvatljive nivoe rizika;

- uspostavljanje mehanizama kontrole procenjenih rizika.

Opasni događaji mogu da uzrokuju otkaze i najčešće su povezani sa određenim faktorima. Po mestu i pravcu delovanja, faktori se mogu podeliti na: spoljne i unutrašnje. 
Spoljni faktori predstavljaju aktivnosti različitih subjekata, događaja ili pojava, a fizički se nalaze izvan organizacije.

Unutrašnji faktori predstavljaju aktivnosti, događaje ili pojave, a fizički se nalaze unutar organizacije.

Unutrašnji faktori najčešće su:

- istorija negativnih/opasnih događaja;

- neusklađenost organizacije sa zakonskom regulativom;

- veličina ili razuđenost organizacije;

- neadekvatan način organizacije rada;
- nedovoljna edukovanost zaposlenih; - postojeći sistemi održavanja opreme. Mogućnost realizacije pojedinih opasnih događaja koji mogu da uzrokuju otkaz prikazuje se nivoom rizika. Nivo rizika je u direktnoj zavisnosti od učestalosti ponavljanja opasnih događaja, osetljivosti sistema, i postojećeg stanja sistema [10].

\subsection{Dijagram toka procene $i$ upravljanja rizikom u postupku održavanja rudarske opreme}

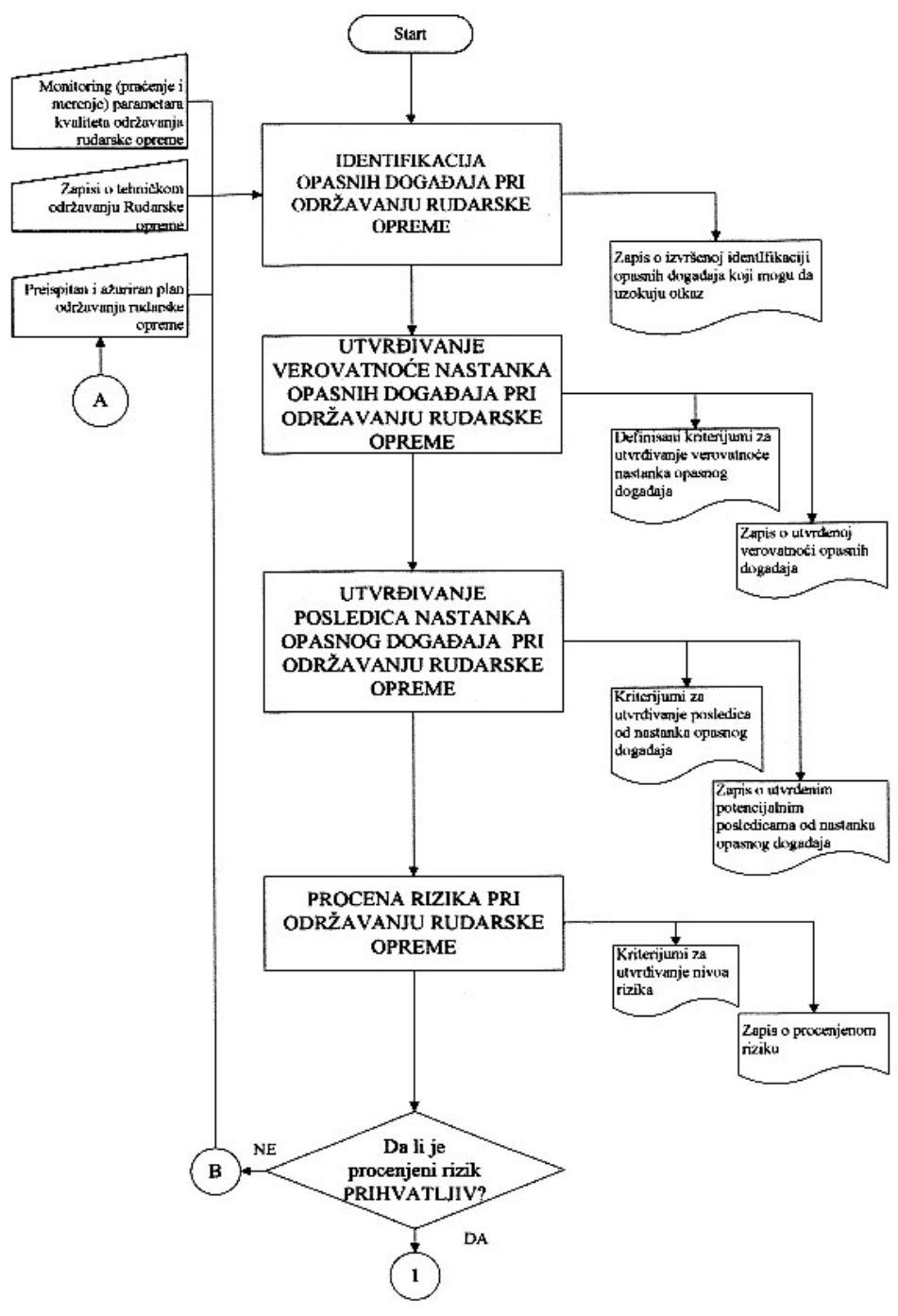




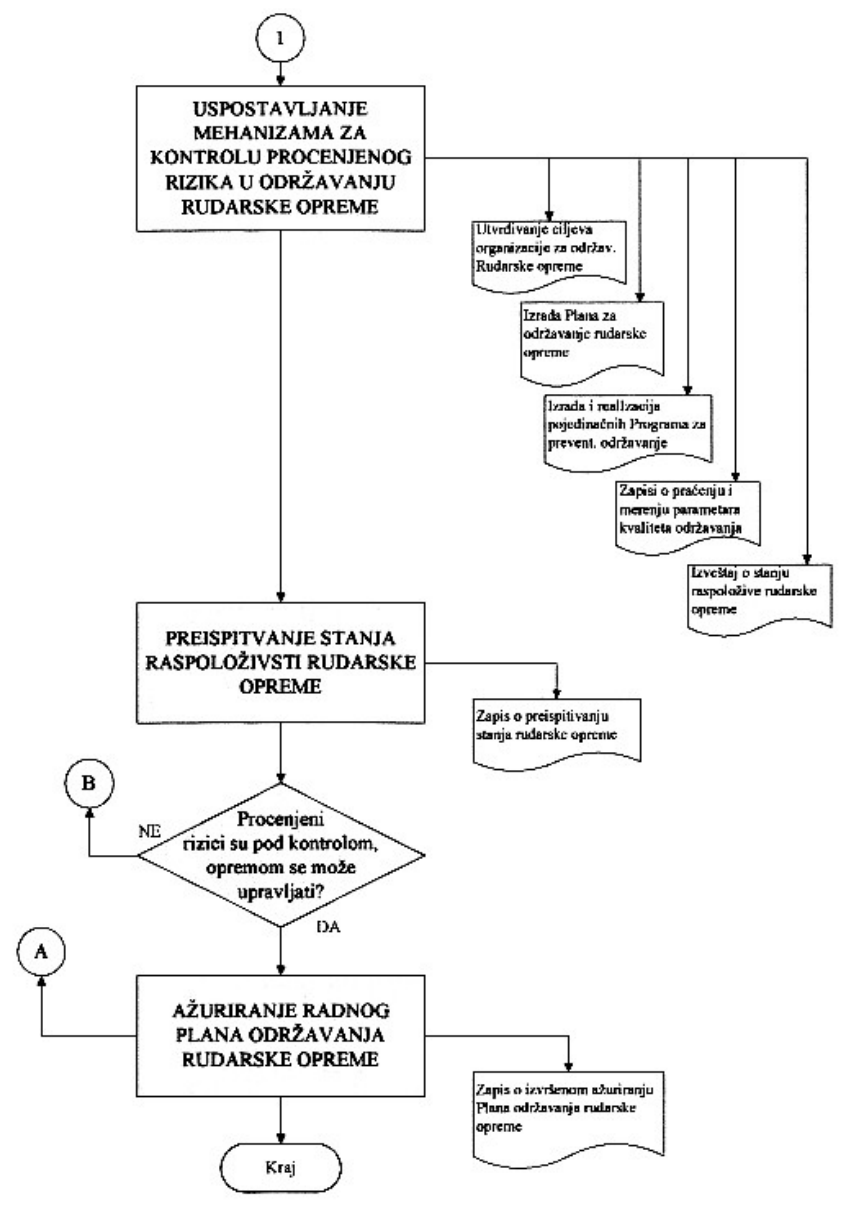

\subsection{Izbor metode i kriterijuma za \\ procenu rizika}

Procena rizika obuhvata verovatnoću pojave opasnih događaja i posledica realizacije opasnog događaja koje mogu da uzrokuju otkaz [12] i može se izraziti na sledeći način.

$$
\mathbf{R}=\mathbf{V} \times \mathbf{P}
$$

gde je:

$\mathrm{R}$ - nivo rizika;

V - verovatnoća da će potencijalna opasnost rezultirati opasnim događajem i uzrokovati otkaz;

P - posledice ili efekat koji opasni događaj može da ostavi na vrednosti orga-

nizacije, prirodne i radom stvorene vrednosti i kvalitet životne sredine.

\subsubsection{Procena verovatnoće opasnog događaja}

Verovatnoća pojave opasnog događaja koji može da uzrokuje otkaz opreme (V) se izražava se prema sledećem izrazu:

$$
\mathbf{V}=\mathbf{U} \# \mathbf{R}
$$

U - učestalost ili frekvencija dešavanja (pojavljivanja) opasnog događaja koji može uzrokovati otkaz opreme; 
R - osetljivost organizacije na mogućnost realizacije opasanog događaja.

Verovatnoća da potencijalna opasnost rezultira opasnim događajem predstavlja kombinaciju učestalosti dešavanja određe- nog opasnog događaja i osetljivosti organizacije. Verovatnoća da potencijalna opasnost rezultira opasnim događajem stepenovana je na sledeći način: 1 - vrlo malo verovatno; 2 - malo verovatno; 3 - umereno verovatno; 4 - verovatno; 5 - vrlo verovatno.

Tabela 1. Kriterijumi za određivanje verovatnoće nastanka opasnog događaja

\begin{tabular}{|c|c|c|c|}
\hline & Učestalost - U & Osetljivost - R & $\mathbf{V}=\mathbf{U} \# \mathbf{R}$ \\
\hline 1 & $\begin{array}{c}\text { vrlo retka } \\
\text { pojava opasnog događaja }\end{array}$ & $\begin{array}{c}\text { vrlo velika } \\
\text { uopšte nema funkcije održavanja }\end{array}$ & $\begin{array}{l}\text { vrlo malo } \\
\text { verovatno }\end{array}$ \\
\hline 2 & $\begin{array}{c}\text { povremena } \\
\text { pojava opasnog događaja }\end{array}$ & $\begin{array}{c}\text { velika } \\
\text { samo organizacione mere održavanja }\end{array}$ & $\begin{array}{c}\text { malo } \\
\text { verovatno }\end{array}$ \\
\hline 3 & $\begin{array}{c}\text { česta } \\
\text { pojava opasnog događaja }\end{array}$ & $\begin{array}{c}\text { srednja } \\
\text { samo tehničke mere održavanje }\end{array}$ & $\begin{array}{c}\text { umereno } \\
\text { verovatno }\end{array}$ \\
\hline 4 & $\begin{array}{c}\text { pretežna } \\
\text { pojava opasnog događaja }\end{array}$ & $\begin{array}{c}\text { mala } \\
\text { organizacione i tehničke mere održavanja }\end{array}$ & verovatno \\
\hline 5 & $\begin{array}{c}\text { veoma česta } \\
\text { pojava opasnog događaja }\end{array}$ & $\begin{array}{c}\text { vrlo mala } \\
\text { u funkciji sistemsko održavanje }\end{array}$ & $\begin{array}{c}\text { vrlo } \\
\text { verovatno }\end{array}$ \\
\hline
\end{tabular}

Učestalost se odnosi na ponavljanje određene pretnje da će doći do realizacije opasnog događaja u posmatranom vremenskom periodu. Učestalost se stepenuje na sledeći način: 1 - vrlo retko; 2 - povremeno; 3 - često; 4 - pretežno; i 5 - veoma često.

Osetljivost predstavlja postojeće stanje sistema održavanja opreme / osnovnih sredstava, odnosno osetljivost organizacije / postrojenja / procesa na opasnost od otkaza.
Osetljivost se stepenuje na sledeći način: 1 vrlo velika ranjivost - uopšte nema mera funkcije održavanja, 2 - velika ranjivost - u funkciji samo organizacione mere održavanja, 3 - srednja ranjivost - u funkciji samo tehničke mere održavanja, 4 - mala ranjivost - $u$ funkciji organizacione i tehničke mere održavanja i 5 - vrlo mala ranjivost - uspostavljen, sertifikovan i više puta proveren sistem menadžmenta opremom.

Tabela 2. Matrica za procenu verovatnoće otkaza

\begin{tabular}{|l|c|c|c|c|c|c|}
\hline \multicolumn{2}{|c|}{ OSETLJIVOST } & vrlo velika & velika & srednja & mala & vrlo mala \\
\cline { 2 - 7 } UČESTALOST & 1 & $\mathbf{2}$ & $\mathbf{3}$ & $\mathbf{4}$ & $\mathbf{5}$ \\
\hline vrlo retko & 1 & 3 & 2 & 1 & 1 & 1 \\
\hline povremeno & 2 & 4 & 3 & 2 & 2 & 1 \\
\hline često & 3 & 5 & 4 & 3 & 2 & 2 \\
\hline pretežno & 4 & 5 & 4 & 3 & 3 & 3 \\
\hline veoma često & 5 & 5 & 5 & 4 & 3 & 3 \\
\hline
\end{tabular}

\subsubsection{Posledice opasnog događaja}

Posledice opasnog događaja (P) se izražavaju prema izrazu:

\section{$\mathbf{P}=\check{\mathbf{S}}$ \# K}

Š - šteta, oštećenje specifične rudarske mehanizacije na kojoj opasan događaj može izazvati posledice;
K - kritičnost, vrednost ili važnost štićene vrednosti za organizaciju u kojoj opasan događaj može izazvati posledice.

Posledice predstavljaju efekat opasnog događaja po opremu (osnovna sredstva) organizacije, a manifestuju se kroz veličinu 
štete u odnosu na kritičnost važnosti štićene vrednosti.

Posledice su stepenovane na sledeći način: 1 - vrlo lake posledice; 2 - lake posledice; 3 - srednje teške posledice; 4- teške posledice i 5 - izrazito teške posledice.

Tabela 3. Kriterijumi za utvrđivanje posledica

\begin{tabular}{|c|c|c|c|}
\hline & Štteta - Š & Kritičnost - K & $\mathbf{P}=\check{\mathbf{S}} \# \mathbf{K}$ \\
\hline 1 & $\begin{array}{c}\text { vrlo mala -do } 1.000,00 \text { Eura ili vrlo } \\
\text { male posledice }\end{array}$ & $\begin{array}{l}\text { vrlo velika- potpuni prekid } \\
\text { funkcionisanja organizacije }\end{array}$ & $\begin{array}{l}\text { vrlo lake } \\
\text { posledice }\end{array}$ \\
\hline 2 & $\begin{array}{c}\text { mala - od 1.000,00 do } 10.000,00 \text { Eura, } \\
\text { ili male posledice }\end{array}$ & $\begin{array}{c}\text { velika- poljuljano } \\
\text { funkcionisanje organizacije }\end{array}$ & lake posledice \\
\hline 3 & $\begin{array}{l}\text { srednja - od } 10.000,00 \text { do } 100.000,00 \\
\text { Eura ili teške posledice }\end{array}$ & $\begin{array}{c}\text { srednja- moguće } \\
\text { funkcionisanje uz povećane } \\
\text { napore i dopunska sredstva }\end{array}$ & $\begin{array}{l}\text { srednje teške } \\
\text { posledice }\end{array}$ \\
\hline 4 & $\begin{array}{l}\text { velika - više od } 100.000,00 \text { Eura, ili } \\
\text { teške i višestruke tešeke posledice }\end{array}$ & $\begin{array}{c}\text { mala- moguće zaustavljanje } \\
\text { procesa rada }\end{array}$ & $\begin{array}{c}\text { teške } \\
\text { posledice }\end{array}$ \\
\hline 5 & $\begin{array}{l}\text { vrlo velika - više od milion Eura, ili } \\
\text { katastrofalne posledice }\end{array}$ & $\begin{array}{l}\text { vrlo mala- rešavanje u hodu, } \\
\text { redovnim aktivnostima }\end{array}$ & $\begin{array}{c}\text { izrazito teške } \\
\text { posledice }\end{array}$ \\
\hline
\end{tabular}

Šteta je mera oštećenja štićene vrednosti (opreme/osnovnih sredstava) i može rezultirati u različitim stepenima. Šteta je stepenovana i izražena kao: 1 - vrlo mala šteta; 2 - mala šteta; 3 - srednja šteta; 4 velika šteta i 5 - vrlo velika šteta.
Kritičnost je mera vrednosti odnosno važnosti štićene vrednosti.

Kritičnost je stepenovana na sledeći način: 1 - vrlo velika kritičnost; 2 - velika kritičnost; 3 - srednja kritičnost; 4 - mala kritičnost i 5 - vrlo mala kritičnost.

Tabela 4. Matrica za procenu posledica

\begin{tabular}{|c|c|c|c|c|c|c|}
\hline \multirow{2}{*}{\multicolumn{2}{|c|}{$\begin{array}{l}\text { KRITIČNOST } \\
\text { ŠTETA }\end{array}$}} & vrlo velika & velika & srednja & mala & vrlo mala \\
\hline & & 1 & 2 & 3 & 4 & 5 \\
\hline vrlo mala & 1 & 3 & 2 & 1 & 1 & 1 \\
\hline mala & 2 & 4 & 3 & 2 & 2 & 1 \\
\hline srednja & 3 & 5 & 4 & 3 & 2 & 2 \\
\hline velika & 4 & 5 & 4 & 3 & 3 & 3 \\
\hline vrlo velika & 5 & 5 & 5 & 4 & 3 & 3 \\
\hline
\end{tabular}

\subsubsection{Definisanje nivoa rizika}
Nivo rizika stepenovan je kao:
1) Vrlo mali (ili zanemarljiv) rizik $(\mathrm{R}=1$ i 2$)$
2) Mali rizik $(R=3,4$ i 5)
3) Umereno povećani $\operatorname{rizik}(\mathrm{R}=6,8$ i 9)
4) Veliki rizik $(\mathrm{R}=10,12,15$ i 16)
5) Izrazito veliki rizik $(\mathrm{R}=20$ i 25).

Tabela 5. Matrica za procenu rizika

\begin{tabular}{|l|c|c|c|c|c|c|}
\hline \multicolumn{2}{|c|}{ POSLEDICE } & vrlo lake & lake & srednje teške & teške & izrazito teške \\
\cline { 3 - 7 } VEROVATNOĆA & 1 & 1 & 2 & 3 & 4 & 5 \\
\hline vrlo malo verovatno & 1 & 2 & 3 & 4 & 5 \\
\hline malo verovatno & 2 & 2 & 4 & 6 & 8 & 10 \\
\hline umereno verovatno & 3 & 3 & 6 & 9 & 12 & 15 \\
\hline verovatno & 4 & 4 & 8 & 12 & 16 & 20 \\
\hline vrlo verovatno & 5 & 5 & 10 & 15 & 20 & 25 \\
\hline
\end{tabular}


Procenjeni rizici se prema definisanoj kategorizaciji svrstavaju u:

1) PRIHVATLJIV RIZIK

$(\mathrm{R}=1,2,3,4$ i 5$)$

2) USLOVNO PRIHVATLJIV RIZIK $(\mathrm{R}=6,8,9)$

3) NEPRIHVATLJIV RIZIK $(\mathrm{R}=10,12,15,16,20$ i 25$)$

Po završetku procesa procene rizika pristupa se uspostavljanju mehanizama kontrole procenjenog rizika. Izbor odgovarajuće opcije za uspostavljanje mehanizama kontrole rizika obuhvata balansiranje troškova i napora u primeni opcije i koristi koja se može iz toga izvući [8].

Veliki broj opcija za uspostavljanje mehanizama kontrole rizika može biti razmatran $\mathrm{i}$ primenjen pojedinačno ili $\mathrm{u}$ kombinaciji. Kod odlučivanja treba uzeti u obzir retke, ali rizike koji mogu opravdati akcije uspostavljanja mehanizama kontrole rizika koje nisu opravdane (dozvoljene) po strogo ekonomskim pravilima [10].

Pri definisanju upravljanja rizikom, ili razmatranja izmena u postojećem upravljanju, moraju se razmotriti mere i opcije smanjivanje rizika u skladu sa sledećom hijerarhijom:

a) mere i opcije za otklanjanje ili izbegavanje rizika;

b) mere i opcije za ublažavanje ili zamenu (substituciju) rizika;

c) mere i opcije za inženjersku kontrolu izvodljivost primenjenih strategija, planova i programa $\mathrm{i}$ analizu odnosa cene i koristi;

d) mere i opcije za definisanje procedura i uputstava za održavanje opreme;

e) mere i opcije za primenu tehničke dijagnostike.

\section{ZAKLJUČCI}

Rudarske kompanije koje žele da unaprede svoja poslovanja moraju da u svakom momentu raspolažu relevantnim informacijama koja oprema/osnovna sredstva su u raspoloživom i funkcionalnom stanju. Analizi stanja opreme/osnovnih sredstava potrebno je da se posveti dovoljna pažnja jer na taj način menadžment preduzeća raspolaže bitnim informacijama koje podstiču donošenje odgovarajućih odluka za unapređenje sistema menadžmenta opremom kao i celokupnim integrisanim menadžment sistemom. Vrlo važan korak u razvoju sistema održavanja opremom je uključivanje najvišeg rukovodstva i osoblja zaduženog za eksploataciju i održavanje opreme.

Definisani dijagram toka i metodološki postupak procene rizika u postuku održavanje opreme/osnovnih sredstavaje od velike koristi za razvoj sistema menadžmenta opremom (AMS). Procena rizika i uspostavljanje kontrolnih mehanizama upravljanja je od velike koristi i pri projektovanju integrisanih sistema menadžmenta [8]. Predloženi model procene rizika omogućava da se informacije o riziku u održavanju opreme adekvatno procesuiraju i koriste u donošenju odluka na releventnim nivoima organizacije [8].

Predložena je i definisana metodologija menadžment rizika u održavanju rudarske opreme koja:

- obezbedjuje da bude proaktivna, a ne reaktivna $\mathrm{i}$,

- obezbeđuje identifikaciju, određivanje prioriteta i dokumentovanost rizika, kao i primenu kontrole, kada je to prikladno.

Proaktivnom i sveobuhvatnom procenom rizika kako je to definisano ovim radom organizacija koja se bavi održavanjem rudarske oprememože da:

- kreira i odobrava politiku upravljanja procenjenim rizikom;

- obaveštava sve zainteresovane strane (poslodavce, menadžment, korisnike,..) za stanje raspoloživosti svoje rudarske mehanizacije;

- definiše mehanizme kontrole procenjenog rizika koji odgovaraju performansama organizacije za održavanje rudarske mehanizacije; 
- osigurava podudarnost ciljeva upravljanja rizikom pri održavanju rudarskih mašina sa ciljevima i strategijom organizacije;

- obezbeđuje usaglašenost sa zakonskom i podzakonskom regulativom kao i sa pravnim aktima organizacije koji se tiču upravljanjakvalitetom održavanja rudarske mehanizacije;

- obezbeđuje raspodelu potrebnih resursa za potrebe upravljanja procenjenim rizikom.

\section{LITERATURA}

[1] Asset Management Consulting Limited brochure: Asset Management excellence (2010)

[2] Australian Emergency Management Committee, 2009: National Emergency Risk Assessment Guidelines, Tasmanian State Emergency Service, Hobart.

[3] Anđelković B., Staletović N., Preventivni inženjering $\mathrm{u}$ oblasti požara $\mathrm{u}$ projektovanju tehnoloških sistema, Preventivni inženjering, br. 2. Dunav Preving, Beograd, 1999, str. 27-31.

[4] BSI: Asset Management-Overview, principles and terminology, ISO PC 251/N48

[5] Curović D., Gavrilović M.; Asset Management - serija standarda ISO 55000; Kvalitet i izvrsnost br. 9-10; Beograd 2012

[6] European standard EN 15341 Maintenance - Key performance Indicators

[7] Kovačević S.; Staletović N.; Tucović N.; Metodološki pristup procene rizika $\mathrm{u}$ funkciji upravljanja sistemom zaštite zdravlja i bezbednosti na radu u JP PK "Kosovo"; Poslovna politika - Kvalitet; ISSN 0354-2408 - UDC 006+658.5; Godina XXI Broj 10 - 11-2011.

[8] Kovačević S., Staletović N., N. Tucović, R. Janković; Quantitative Asse- ssment of Risk Management in the Function of Integrated Systems, 14. DQM Međunarodna konferencija Upravljanje kvalitetom i pouzdanošću ICDQM - 2011, (ISBN 978-8686355-05-8, pp. 159-165), 29-30. jun 2011. godine. Beograd, Srbija.

[9] Petrović D., Damnjanović Z., Đenadić D., Pantović R., Milić V., Primena modernih računarskih uređaja i alata za smanjenje akcidentnih situacija $u$ rudarskim sistemima Rudarski radovi, Bor, br. 2, str. 29-40, 2010

[10] Staletović N, Kovačević S., Kovačević M.; Metodološki pristup identifikacije aspekata i vrednovanje uticaja na životnu sredinu za projekat »Eksploatacija magnezita u ležištu Čavlovac Masnica«; Rudarski radovi 2012; ISSN 1451-0162

[11] Staletović N.; Ocena OH\&S rizika u funkciji preventivnog inženjeringa $\mathrm{i}$ integrisanih sistema menadžmenta (QMS/EMS/OHSAS); Tehnika - Menadžment, vol. 59, br. 3, str. 8-14, 2009.

[12] Standard IEC/FDIS 31010:2009(E) Risk management — Risk assessment techniques

[13] Standards Australia and Standards New Zealand; Standard Risk Management AS/NZS 4360:2009. Sydney and Wellington: Standards Australia and Standards New Zealand.

[14] Papić Lj.; Preventivno održavanje, Istraživački centar DQM, Čačak, 1998, 109 str.

[14] Papić Lj., Milovanović Z; Održavanje i pouzdanost tehničkih sistema, DQM, Prijevor, 2007

[16] www.umsgroup.com

[17] www.pragma world.net

[18] http://en.wikipedia.org/wiki/ Asset_management

[19] http://theiam.org/what-assetmanagement 